Niepełnosprawność. Dyskursy pedagogiki specjalnej

Anna Majer

Anna Nawrocka

Akademia Wychowania Fizycznego i Sportu w Gdańsku

\title{
Problematyka niepełnosprawności w telewizyjnych bajkach dla dzieci
}

W artykule przedstawiono wyniki analizy telewizyjnych bajek dla dzieci „Reksio” oraz „Cliffordwielki czerwony pies”. W badaniu skoncentrowano się na analizie problematyki niepełnosprawności obecnej w obu produkcjach. Na wstępie ukazano znaczenie mediów masowych jako istotnych czynników socjalizacji i edukacji. Pokazano stanowiska badaczy współczesnej kultury w tym aspekcie. Następnie, prezentując wyniki analizy bajki „Reksio” oraz „Clifford - Wielki czerwony pies", pokazano w jaki sposób prezentowana jest interesująca nas problematyka niepełnosprawności. Na koniec, podkreślając potencjał socjalizacyjno-edukacyjny bajek dla dzieci, ukazano sposób wykorzystania wyników badań w praktyce edukacyjnej.

Słowa kluczowe: niepełnosprawność, media, bajki dla dzieci, socjalizacja, edukacja

\section{Disability in TV cartoons for kids}

The article presents the results of the analysis of TV cartoons for kids "Reksio" and "Clifford - the Big Red Dog". The study was focused on the analysis of disability depicted in both films. The initial part of the article is a discussion about the importance of mass media as the important factor of socialization and education, including the researchers' views on this particular aspect. The next part of the paper is a results section, where we report the findings of the analysis of the films "Reksio" and "Clifford - the Big Red Dog", pointing out the ways disability plot is featured in children's animated movie. Eventually, emphasizing the impact of children's animated movie on socialization and education, the authors show how to use a performed results of the study in practice.

Keywords: disability, media, fairy tales for children, socialization, education

\section{Wprowadzenia do problematyki - media masowe jako czynnik socjalizacji i edukacji}

W dzisiejszych czasach media masowe, a więc prasa, radio, telewizja i w ostatnich latach Internet, grają w życiu członków naszego społeczeństwa coraz większą rolę. Współczesny człowiek jest zanurzony w świecie przez nich tworzonym - 
w codziennym życiu właściwie nieustannie otaczany jest przez treści, teksty, które płyną do niego z owych mediów. Jak twierdzą badacze współczesnej kultury, dziś media odgrywają niebagatelną rolę $\mathrm{w}$ procesie socjalizacji, czyli $\mathrm{w}$ „procesie nabywania przez jednostkę wiedzy, systemu wartości, biegłości językowej, umiejętności społecznych i społecznej wrażliwości, który pozwala zintegrować się ze społeczeństwem i zachowywać w nim przystosowawczo" [Reber 2002, za: Tanaś 2008, s. 197]. Odgrywają także dużą rolę w procesach edukacyjnych, które pozwalają przygotować jednostki do „działalności zawodowej, udziału w życiu gospodarczym, uczestnictwa społecznego, kształtowania losów osobistych" [Szymański 2013, s. 7] Dziś, jak zauważa Zbyszko Melosik, w praktyce mamy do czynienia ze swoistym "przesunięciem socjalizacyjnym" - tradycyjne instytucje socjalizacji (rodzina, szkoła, kościół) tracą na znaczeniu, a ich role przejmują w sposób inwazyjny: grupa rówieśnicza oraz mass media i szeroko rozumiana kultura popularna" [Melosik 2006, s. 68]. Rozmaite teksty kultury popularnej, rozpowszechniane za pomocą mediów, w coraz szerszym stopniu kształtują tożsamość współczesnego człowieka [por. Melosik 1996, s. 21; Ćwikliński 2010, s. 270].

Oczywiście media masowe to specyficzny instrument socjalizacji oraz edukacji. Nie ma tu często zamierzonego efektu wpływu, ale jak zauważa Tanaś: „Nawet jeśli owa rola jest pośrednia, to i tak media są znaczącym źródłem socjalizacji, oprócz rodziny, rówieśników i osób znaczących z kręgu znajomych, a także szkoły i kościoła. Problem jednak nie tkwi w tym, że są ożywczym źródłem, a w tym, że wartki nurt obrazów i słów, który z nich wypływa, w wyjątkowych tylko przypadkach ma ten sam kierunek i cel, co zamierzone i realizowane w szkole działania wychowawcze" [Tanaś 2008, s. 197].

Andrzej Ćwikliński zauważa, analizując edukacyjny potencjał płynący z przekazu z mediów, iż „można zaryzykować pogląd, że tożsamość młodych ludzi jest konstruowana poprzez opozycyjne wobec siebie formy życia społecznego, jakimi najczęściej są formalna edukacja, realizowana w szkole oraz edukacja nieformalna, która jest wynikiem oddziaływań kultury popularnej" [Ćwikliński 2010, s. 271].

A zatem obok rodziny, media i rozpowszechniana przez nie kultura popularna, stają się głównym czynnikiem, instrumentem tych procesów. Oczywiście taką funkcję pełnią nie od dziś, ale na pewno w ostatnich latach ich oddziaływanie z oczywistych względów - rozszerzyło się i wzmocniło.

\section{Problem niepełnosprawności w przekazie medialnym}

W związku z tym, że media masowe będąc istotnymi czynnikami socjalizacji i edukacji przekazują wzorce zachowań, normy postępowania, wartości, obraz 
świata czy wiedzę o świecie, warto przyjrzeć się przekazowi z nich płynącemu. Dlatego też $\mathrm{w}$ niniejszym artykule skoncentrowano się na wynikach analizy filmów animowanych dla dzieci, w których to poszukiwano kwestii związanych z problematyką niepełnosprawności. Samo pojęcie niepełnosprawności doczekało się na przestrzeni wielu lat licznych definicji i interpretacji.

Aleksander Hulek określa osobę niepełnosprawną jako: „osobę, która na skutek ograniczeń pod względem fizycznym (motorycznym, sensorycznym), somatycznym lub psychicznym ma znaczne trudności w wywiązaniu się z zadań jakie stawia przed nią życie codzienne, szkoła, praca zawodowa i czas wolny" [Hulek 1986, s. 37]. Oprócz wątku medycznego należy zwrócić również uwagę na aspekt funkcjonalny opisujący człowieka niepełnosprawnego jako takiego, który „nie może samodzielnie, częściowo lub całkowicie, zapewnić sobie możliwości normalnego życia, indywidualnego lub społecznego na skutek wrodzonego lub nabytego upośledzenia sprawności fizycznych lub psychicznych" [Bulenda, Zabłocki 2003, s. 371]. Istotny jest więc kontekst społeczny niepełnosprawności - Amadeusz Krause zauważa, że w tym przypadku „(...) chodzi o zmianę pozycji w zbiorowości i podejścia do sytuacji niewydolności psychofizycznej, o przeciwdziałanie stygmatyzacji i wykluczeniu, o integrację i akceptację", a także kontekst kulturowy, gdzie jak zaznacza wspomniany autor - chodzi o "równouprawnienie stylów, tolerancję wobec inności, przyzwolenie na różnorodność kulturową" [Krauze 2010, s. 111].

Jak zauważa Zdzisław Kazanowski, perspektywa społeczna jest obecnie głównym obszarem analizowania zjawiska niepełnosprawności. Obszarem alternatywnym dla medykalizacji, która to lokalizując wadę w strukturze biologicznej jednostki, nawoływała do podjęcia jej leczenia, co w efekcie prowadziło do alienacji społeczno-politycznej osoby niepełnosprawnej, uznawszy ją za „wadliwą [Kazanowski 2011, s. 14]. Wspomniana perspektywa społeczna akcentuje, że osoba niepełnosprawna jest jednak przecież integralną cząstką społeczeństwa [Kosakowski 1996, s. 100]. Jest postrzegana jako pełnoprawny członek społeczności, którego prawa człowieka dotyczą w takim samym stopniu jak pozostałej reszty społeczeństwa.

W przeciągu zaledwie kilku ostatnich lat mass media - zwłaszcza telewizja szerzej zajęły się tematyką obecności i funkcjonowania społecznego osób niepełnosprawnych i użyczyły im swojej przestrzeni antenowej. Pomimo wielu kampanii społecznych i większego dostępu do wiedzy na temat niepełnosprawności, wielu odbiorców telewizyjnych zdziwić jednak może widok człowieka dotkniętego poważną chorobą lub kalectwem na ekranie telewizyjnym - szczególnie jako głównego albo drugoplanowego bohatera filmu, serialu czy teatru telewizyjnego a już zwłaszcza wówczas, kiedy dysfunkcje ruchowe lub zmiany cielesne są dostrzegalne i wyraźnie widoczne. 
Jak zauważa Anna Bieganowka: „Często ukazuje się niepełnosprawnych jako tych, dzięki którym pełnosprawni odkrywają siebie lub odnajdują utracony sens życia. Jako przykład wystarczy przytoczyć następujące tytuły filmów: Ósmy dzień czy Forrest Gump. Dziwi tylko fakt, że równie często pod koniec takiego filmu niepełnosprawny umiera lub zostaje oddany do przytułku. Może to sugerować widzowi, że niepełnosprawność jest zjawiskiem zbyt trudnym do zaakceptowania przez społeczeństwo" [Bieganowska 2004a, s. 44-46].

Wspomniana autorka stoi również na stanowisku, że bardzo często można zauważyć, iż obok wizerunku osoby niepełnosprawnej ukazanej jako cierpiętnika, media ukazują portret super bohatera-inwalidy, człowieka, który „pomimo swojego inwalidztwa" bardzo wiele osiągnął, któremu przypisuje się niezwykłe cechy, dostrzega się w nim liczne talenty i umiejętności. Ma to służyć nie tylko osobom niepełnosprawnym, ale też całej reszcie społeczeństwa. Tym pierwszym ma to dodać otuchy i wiary w siebie, uzmysłowić, że niepełnosprawność nie musi być przeszkodą w codziennym życiu; u drugich natomiast - zmniejszyć niechęć i obawę przed osobami niepełnosprawnymi [Bieganowska 2004b, s. 44-46].

Wybór filmów dla dzieci jako materiału do analizy nie jest przypadkowy. Sam wpływ mediów na tę kategorię społeczną jest różnie oceniany [por. Karkowska 2007; Szymański 2013]. Jednak, jak zauważa David Buckingham, „Niezależnie od tego czy wpływ nowych mediów na dzieci ocenia się jako pozytywny, czy negatywny, istnieje dość jednolity pogląd, że media dysponują nadzwyczaj potężnymi możliwościami modelowania świadomości dzieci, określania ich tożsamości i dyktowania wzorców powielanych często w codziennym życiu" [Buckingham 2008, s. 151].

Co więcej, jak twierdzi Maciej Tanaś, świat ukazywany przez media odciska się głębokim trwałym śladem w umyśle dziecka, gdyż - jak zaznacza wspomniany autor - „media (...) nie tylko przekazują informacje, lecz rodzą emocje, kształtując sferę wyobraźni, budzą pragnienia i marzenia, mieszając hierarchię wartości i realizując zadania tylko niekiedy zbieżne z oczekiwaniami pedagogów i nauczycieli" [Tanaś 2008, s. 198].

Mając to na uwadze, $\mathrm{w}$ badaniu przekazu medialnego, analizie poddano zawartość fabuły dwóch bajek - Reksia oraz Clifforda Wielkiego Czerwonego Psa (Clifford the Big Red Dog), konkretnie szukając w nich wątków na temat niepełnosprawności zgodnie z przywołaną na wstępie tego artykułu definicją.

Warto jednak zauważyć, że niepełnosprawność, oprócz trwałego charakteru, może mieć czasowy lub okresowy wymiar. W takich przypadkach trafnym byłoby użycie definicji podkreślającej jej charakter czasowy: „Niepełnosprawnymi są osoby, których stan fizyczny, psychiczny lub umysłowy trwale lub okresowo utrudnia, ogranicza bądź uniemożliwia wypełnianie ról społecznych (...)" [Dz. U. z 2011 r. Nr 127]. 


\section{Analiza bajek telewizyjnych dla dzieci - przekaz o niepełnosprawności}

Analizie poddano dwie bajki: polską i amerykańską. Wspólnym mianownikiem obu bajek jest postać głównego bohatera obsadzonego w postaci psa - symbolu najlepszego przyjaciela człowieka. Zarówno Reksio, jak i Clifford cieszyły i nadal cieszą się ogromną popularnością wśród młodych widzów. Niosą za sobą przekaz odnoszący się do ponadczasowych problemów i wartości (przyjaźni, uczynności, uczciwości, honorowych postaw czy też, co dla nas istotne, do oswajania widza z problematyką niepełnosprawności). Badania były prowadzone na podstawie analizy serii bajek na przestrzeni od kwietnia do czerwca 2017 roku.

\section{Reksio}

Serial animowany dla dzieci o tytułowym psie Reksiu był produkowany w latach 1967-1990 przez Studio Filmów Rysunkowych w Bielsku-Białej. Nakręcono w sumie 65 odcinków. Jest to jedna z najbardziej popularnych i znanych bajek typu wieczorynka, oglądana zarówno przez starsze pokolenie, jak i najmłodszych widzów, wyświetlana w telewizyjnych stacjach do dnia dzisiejszego. Główny bohater, pełniąc funkcję przewodnika po świecie, mierzy się z różnymi problemami i życiowymi sytuacjami, zawsze znajdując dobre zakończenie.

Jak po latach wspomina jeden z współtwórców bajki - Lechosław Marszałek: „Psiak Reksio przybliżył dzieciom świat zwierzęcy. Poprzez jego codzienne przygody, rozgrywające się w sferze dziecięcej wyobraźni, starałem się wszczepić milusińskim potrzebę miłości do zwierząt, oczekujących od człowieka serdeczności i troskliwości. Dzieci, które lubią zwierzęta, są bogatsze w przeżycia wewnętrzne, żądne poznania nowego świata. Te zaś, które lękają się bądź też ich nie lubią, bywają zubożone o wartość taką jak przyjaźń człowieka ze zwierzęciem. I te aspekty, wzbogacone warstwami moralizatorskimi i wychowawczymi, przyświecały mi $\mathrm{w}$ toku realizacji kolejnych filmów" [Wanat 2017].

Analiza wszystkich odcinków wykazała, że interesująca nas kwestia jaką jest niepełnosprawność, również znalazła się $\mathrm{w}$ fabule kilku odcinków. To interesujące, gdyż już w latach 70. XX wieku ta problematyka wydawała się autorom bajki ważna i znacząca. Przyjrzyjmy się tej kwestii w porządku chronologicznym powstawania odcinków.

Już w piątym z kolei wyprodukowanym odcinku pojawia się interesująca nas problematyka. W odcinku pt. Reksio Dobroczyńca (1970) główny bohater, na początku dzieli się jedzeniem z głodnym, bezdomnym psem. W dalszej części odcinka, idąc ulicą, zauważa niepełnosprawnego, niewidomego starszego mężczyznę, któremu 
pomaga przejść przez ulicę. Spotkanie to pozostaje w pamięci Reksia i gdy znowu odwiedza go bezdomny, głodny pies, główny bohater serii wpada na pewien pomysł. Pokazuje owemu psu jak to jest być niewidomym (zawiązując mu oczy). Następnie sam sobie zawiązuje oczy i uczy bezdomnego psa jak należy prowadzić niewidomego, jak przeprowadzać przez ulicę, jak reagować na sygnalizację świetlną. Wszystko to ma na celu pomoc zarówno szkolonemu psu (aby znalazł wreszcie upragniony dom), jak i niewidomemu mężczyźnie w sprawnym poruszaniu się po ulicy oraz posiadaniu psa do towarzystwa. W analizowanym odcinku niepełnosprawność pokazana jest jako coś co powoduje pewne problemy w życiu, które jednak w szybki, łatwy i przyjemny sposób, z korzyścią dla wszystkich stron, mogą być usunięte. Jak w większości odcinków Reksia, wyraźnie eksponowana jest tu kwestia pomocy potrzebującym.

W odcinku pt. Reksio Terapeuta (1979), okazuje się, że jednej z kurczaków, jakie niedawno wykluły się mieszkającej w zagrodzie Reksia kurze, jest niepełnosprawny - nie może chodzić. Tradycyjnie główny bohater stara się pomóc potrzebującemu. Szuka sposobu, aby kurczak mógł swobodnie się poruszać - z samochodziku-zabawki robi mu pojazd, przywołujący skojarzenie z wózkiem inwalidzkim. Czas mija, kurczak dorasta i okazuje się, że w wyniku poruszania się w owym pojeździe, ma bardzo mocno ukształtowane skrzydła, które są również dużo większe niż skrzydła pozostałych kurczaków. Pojawiają się sceny, w których ukazane jest w jaki sposób niepełnosprawny kurczak uczy się różnych codziennych czynności - np. polowania na muchy, czyli zdobywania pokarmu. Siłą rzeczy robi to inaczej, ale równie efektywnie jak pozostali bracia, a może nawet lepiej. Reksio postanawia wykorzystać fakt, że niepełnosprawny kurczak ma takie potężnie rozwinięte skrzydła i uczy go latać. W efekcie w sytuacji zagrożenia, gdy nagle jastrząb porywa jednego z kurczaków, niepełnosprawny kurczak leci, używając swych silnych umięśnionych skrzydeł, walczy z agresorem, po czym ratuje brata z opresji. Zostaje bohaterem. W odcinku tym mamy zatem obraz niepełnosprawności pokazujący, że inny to nie znaczy gorszy. Pokazujący, że inny może być lepszy, bardziej efektywny, silniejszy, że kształtując pewne umiejętności może sobie lepiej radzić niż przeciętna osoba. W analizowanym odcinku, zgodnie z tym o czym mówiła cytowana wcześniej Anna Bieganowska, ukazany jest portret inwalidy - super bohatera, posiadacza niezwykłych cech i umiejętności. Pokazuje się również, że niepełnosprawność nie musi być przeszkodą w codziennym życiu.

W serii o Reksiu mamy również do czynienia z niepełnosprawnością czasową, np. gdy główny bohater pielęgnuje psa potrąconego przez samochód, który ma złamane nogi (Reksio Pielęgniarz), czy gdy opiekuje się bocianem ze złamanym skrzydłem, któremu nie udało się odlecieć na zimę (Reksio i Bocian). Wszędzie tam eksponowana jest troska, pomoc innym, choć, jak się okazuje, nie zawsze adresat 
tej troski postępuje fair - pies z pierwszego przykładu zaczyna wykorzystywać dobroć Reksia i udaje chorego, mimo że już jest w pełni sprawny. Nasz bohater pokazuje jednak, że potrafi sobie poradzić i w takiej sytuacji.

\section{Clifford}

Jest to amerykański serial animowany wyprodukowany w latach 2001-2003, oparty na serii książek dla dzieci autorstwa Normana Bridwella, które następnie zostały zekranizowane. Serial opowiada o wielkim czerwonym psie Cliffordzie, którego właścicielką jest mała dziewczynka o imieniu Emily Elizabeth Howard. Łącznie w dwóch seriach wyprodukowano 65 odcinków. Tytułowy bohater Clifford, jak sama Emily Elizabeth go opisuje w jednym z pierwszych, jest cały czerwony, sięga do drugiego piętra i jest o wiele większy od słonia. Zawsze jest gotowy, gdy ktoś potrzebuje jego pomocy. Początkowo był malutkim szczeniakiem. Bał się, że nie urośnie, lecz otoczony opieką i miłością wyrósł na ogromnego psa. Clifford jest bardzo pomocny i opiekuńczy, chętnie stawia czoła wyzwaniom i pomaga nie tylko swoim przyjaciołom, ale również każdej osobie i zwierzęciu, które jest w potrzebie. Clifford przyjaźni się z Cleo. Jest to miła i sympatyczna, choć dość niesforna, pudlica oraz z T- Bonem - małym, żółtym buldogiem, który jest serdeczny i pomocny, choć bardzo strachliwy.

Tę trójkę przyjaciól spotyka wiele niespodzianek razem przeżywają wiele przygód zawsze zabarwionych wątkiem edukacyjnym, który jest jasno przedstawiony w serialu i dzięki temu staje się czytelny dla młodych widzów. Wątek niepełnosprawności jest $\mathrm{w}$ tym serialu nieco inaczej przedstawiony niż $\mathrm{w}$ opisywanym powyżej Reksiu. Clifford w odróżnieniu od Reksia na początku, kiedy styka się z niepełnosprawnością fizyczną u jednego z bohaterów drugoplanowych, nie wie do końca jak powinien się zachować - w jaki sposób i czy w ogóle powinien mu pomóc? Popełnia drobne gafy, ale z czasem uczy się jak powinien traktować osoby niepełnosprawne. Doskonałym przykładem jest odcinek ósmy pierwszej serii noszący tytuł "New friend". W odcinku tym Clifford i jego przyjaciele Cleo i T-Bon spacerując ulicą zostają zaczepieni przez wesołego psa o imieniu Keysi. Pies rozmawia z nimi przez ogrodzenie dzielące ulicę od ogrodu domu, w którym przebywa. Na początku przyjaciele są zachwyceni cechami Keyse'go, tym, że jest taki wesoły i chce się z nimi bawić, poznać okolice (opowiada, że jest tu na wakacjach i nigdy nie był ani na plaży ani nad morzem). Na propozycję wspólnego zwiedzania psy reagują wielkim zadowoleniem. Kiedy Keysi dobiega do bramki i ją otwiera, wszyscy zauważają, że pies ma tylko trzy łapy, co budzi w nich zdziwienie i pewną obawę. Cleo myśli o tym, aby zrezygnować z wspólnego w wyjścia na plażę - nie wie jak Keysi da sobie radę z łapaniem piłki. Kiedy jednak idą wszyscy razem przez ulicę, Keysi pokazuje wszystkim, że jest szybki, sprawny i bardzo 
sprytny. T-bon nie może mu dorównać w bieganiu. Na plaży psy bawią się świetnie i okazuję się, że niepełnosprawny kompan jest wspaniałym kolegą. W kolejnych odcinkach ich znajomość przeradza się prawdziwą przyjaźń. W analizowanym odcinku, niepełnosprawność pokazana jest jako coś co budzi w otoczeniu pewne obawy, obawy jak postępować z takimi osobami, i czy poradzą sobie one w codziennym funkcjonowaniu. Jak w większości odcinków Clifforda, wyraźnie eksponowana jest tu kwestia przyjaźni oraz pomocy potrzebującym, kładzie się tu nacisk na tolerancję i brak strachu przed innością - niepełnosprawnością. Pokazuje się, podobnie jak w jednym z analizowanych odcinków Reksia, że niepełnosprawny jest taki sam, a nawet lepszy od pełnosprawnych towarzyszy. W kolejnych odcinkach zarówno pierwszej, jak i drugiej serii postać Keyse'go pojawia się cyklicznie i zawsze jest on przedstawiany w sposób zwyczajny - jako pies, jako kolega. Problem jego niepełnosprawności nie zostaje zaakcentowany. Wszystkie wątpliwości dotyczące niepełnosprawności zostały rozwiane w wyżej opisanym odcinku.

\section{Zakończenie}

Wartość edukacyjna i wychowawcza bajek jest pokazywana w wielu badaniach naukowych. Dorota Simonides zauważa, że „Baśń ukazuje przykłady dobrego zachowania, uczy właściwego postępowania, zawiera wspaniałe morały, ukazuje dobro i zło, a także może wiele nauczyć" [Simonides 1978, s. 116].

Maria Tyszkowa zauważa, że baśnie i bajki opierają się na metaforze: „łączą w sobie elementy świata realnego i fikcji, dzięki czemu przeskakują nad znanymi układami rzeczywistości, tworząc jej nową poetycką wizję" [Tyszkowa1978, s. 136]. Inny znany badacz Jean Piaget wyjaśnia ponadto, że „Personifikacja i antropomorfizacja zjawisk rzeczywistości, jaka ma miejsce w baśniach, sprawia, że świat przedstawiony jest dla dziecka bliski i zrozumiały, odpowiada bowiem wartościom dziecięcego myślenia i ujmowania rzeczywistości" [Piaget 1966].

Wśród badań na temat przekazu medialnego bajek brakuje nadal badań poruszających kwestię niepełnosprawności i oswajania z nią najmłodszych w sposób naturalny. Taką próbę podjęła Karolina Więckowska w pracy Wizerunek osób niepetnosprawnych w filmach rysunkowych dla dzieci [Więckowska 2010, s. 138-145].

Mając na uwadze to, że temat niepełnosprawności nie jest zbyt często i chętnie podejmowany przez rodziców $\mathrm{w}$ rozmowach $\mathrm{z}$ dziećmi, a nawet przez nauczycieli, że pozornie brakuje przykładów tego zjawiska w życiu codziennym, ze względu na ciągłą nieobecność niepełnosprawności w przestrzeni publicznej w Polsce warto pochylić się nad takimi kanałami przepływu treści, jak mass media 
i zobaczyć jaki potencjał ze sobą niosą. Dzięki nim dzieci mają po prostu szansę zetknąć się z tematem i co byłoby tu szczególnie pożądane, wraz z dorosłym omówić $\mathrm{i}$ ustosunkować się do odbieranych treści.

Jak bowiem zauważają M. Brol i A. Skorupa, film „stanowi potężne narzędzie ilustrowania określonych zagadnień" [Brol, Skorupa 2016, s. 176]. Dzięki opracowanym przekazom medialnym w postaci bajek telewizyjnych, które w naturalny sposób poruszają temat niepełnosprawności, dzieci mogą przekonać się, że wszyscy bez względu na stopień sprawności jesteśmy wartościowymi członkami społeczeństwa. Umożliwia to więc oswojenie przedszkolaków i uczniów z tematem, który jak zaznaczono wyżej, przez wielu rodziców i nauczycieli wciąż uważany jest jako trudny. Przywołajmy w tym kontekście słowa Zbyszko Melosik, który twierdzi, że „Media czynią ludzi otwartymi na nowe doświadczenia, uczą tolerancji wobec różnicy i różnorodności" [Melosik 2008, s. 120]. Młodzi odbiorcy zatem z łatwością przyswajają informacje na temat ludzkiej różnorodności, a dzięki pozyskanej wiedzy mają szanse wyrosnąć na otwartych i mądrych ludzi szanujących wszystkich członków społeczeństwa i siebie nawzajem.

Potencjał socjalizacyjno-edukacyjny jaki niosą ze sobą treści analizowanych bajek telewizyjnych w kontekście problematyki niepełnosprawności jest, jak zostało wyżej wykazane, niezwykle istotny. Przekazują one dziecku określone wartości, wzorce postępowania, uwrażliwiają na temat, który nie zawsze jest dla nich dostępny bezpośrednio w codziennym doświadczeniu. Wreszcie zachęcają do zachowań prospołecznych, pokazują, że warto pomagać potrzebującym, a istoty niepełnosprawne nie są wcale gorsze, mogą być równie dobrze w czymś lepsze od pełnosprawnych członków społeczeństwa. Pokazują, że przyjaźń i szacunek nie zna granic.

\section{Bibliografia}

Bieganowska A. (2004), Niepetnosprawni w mediach [w:] Obyczaje - magazyn międzynarodowy, t. 18-19, Ośrodek „Brama Grodzka - Teatr NN”.

Bulenda T, Zabłocki J., (2003) Ludzie niepełnosprawni w środowisku społecznym [w:] Pedagogika społeczna. Człowieka w zmieniającym się świecie, T. Plich, i. Leparczyk (red.), Żak, Warszawa.

Brol M., Skorupa A. (2016), Film jako narzędzie edukacji - perspektywa psychologiczna [w:] Pedagogika kultury popularnej - teorie, metody i obszary badań, W. Jakubowski (red.), Oficyna Wydawnicza „Impuls”, Kraków.

Buckingham D. (2008), Nowe media - nowe postaci dzieciństwa? Zmieniajace się środowisko kulturowe dzieci w erze technologii cyfrowej [w:] Wprowadzenie do badań nad dzieciństwem, oprac. M.J. Kehily, przeł. ks. M. Kościelak, Wydawnictwo WAM, Kraków.

Ćwikliński A. (2010), Pomiędzy oddziaływaniem szkoły i kultury popularnej. Dylematy tożsamościowe wspótczesnej młodzieży [w:] Kultura popularna - Tożsamość - Edukacja, D. Hejwosz, W. Jakubowski (red.), Oficyna Wydawnicza „Impuls”, Kraków. 
Dziennik Ustaw z 2011 r. Nr 127, poz. 721 ze zm.

Hulek A.(1986), Człowiek niepetnosprawny w społeczeństwie, PZWL, Warszawa.

Karkowska M. (2007), Socjologia wychowania. Wybrane elementy, Wydawnictwo WSH-E w Łodzi, Łódź.

Kazanowski Z. (2011), Przemiany pokoleniowe postaw wobec osób upośledzonych umystowo, Wydawnictwo Uniwersytetu Marii Curie-Skłodowskiej, Lublin.

Kosakowski Cz. (1996), Podmiotowość i autorewalidacja w pedagogice specjalnej [w:] Roczniki Pedagogiki Specjalnej, J. Pańczyk (red.), t. 7, Wydawnictwo Wyższej Szkoły Pedagogiki Specjalnej, Warszawa.

Krauze a. (2006), Następstwa globalnych i lokalnych przeobrażeń społecznych dla jakości życia osób niepetnosprawnych [w:] Jakość życia osób niepetnosprawnych i nieprzystosowanych społecznie, Z. Palak (red.), Wydawnictwo Uniwersytetu Marii Curie- Skłodowskiej, Lublin.

Krause A. (2010), Niepetnosprawność - Inny w paradygmacie humanistycznym, „Niepełnosprawność" nr 4.

Melosik Z. (1996), Tożsamość ciało i władza. Teksty kulturowe jako (kon)teksty pedagogiczne, Edytor, Poznań-Torun.

Melosik Z. (2006), Kultura popularna jako czynnik socjalizacji [w:] Pedagogika, Z. Kwieciński, B. Śliwerski (red.), t. 2, Warszawa, PWN.

Melosik Z. (2008), Mass media i przemiany kultury wspótczesnej [w:] Pedagogika medialna, B. Siemieniecki (red.), t. 1, Warszawa PWN

Piaget J (1966), Studia z psychologii dziecka, Warszawa.

Simonides D. (1978), Fantastyka baśni i innych tekstów folklorystycznych w życiu dziecka, Warszawa

Szymański M.J. (2013), Socjologia edukacji. Zarys problematyki, Oficyna Wydawnicza „Impuls”, Kraków.

Tanaś M. (2008), Wychowanie a media [w:] Pedagogika medialna, B. Siemieniecki (red.), PWN, Warszawa.

Tyszkowa M. (1978), Baśń i jej recepcja przez dzieci [w:] Baśń i dziecko, H. Skrobiszcwska (red.), Warszawa.

Wanat E. (2017), Reksio kończy 50 lat. Przekonywat, że nie można zamykać się w swojej budzie, a poznanie języka obcego pozwala poszerzyć horyzonty, http://weekend.gazeta.pl/weekend/ 1,152121,21376320,reksio-konczy-50-lat-przekonywal-ze-nie-mozna-zamykac-sie.html [dostęp: 09.07.2017].

Więckowska K. (2010), Wizerunek osób niepetnosprawnych w filmach rysunkowych dla dzieci, Wydawnictwo Akademii Pedagogiki Specjalnej im. Marii Grzegorzewskiej, Warszawa. 